\title{
RESPONSE OF WINTER RYE TO HYPERPHOSPHATE AND SUPERPHOSPHATE
}

\author{
Armi KaIla \\ University of Helsinki, Department of Agricultural Chemistry \\ and \\ Pentti Hänninen \\ Agricultural Research Centre, Movable field experiments in Central Finland
}

Received December 16, 1960

In a previous paper (5) the authors reported results of two field trials in which the response of ley plants to hyperphosphate and to superphosphate was compared. No differences were found between the increases in the dry matter yield produced by equal amounts of phosphorus in these fertilizers. The phosphorus content of the red clover-timothy hay was, however, distinctly lower in the hyperphosphate plots, owing to the fact that timothy was able to take up far less phosphorus from hyperphosphate than from superphosphate.

These field trials were carried on with winter rye, a crop which under our conditions is known to require a good supply of phosphorus, not least in overwintering. The development of the rye plants and their uptake of phosphorus were continuously followed since the beginning of the growing period in May. In addition to the analyses of the yield, also the phosphorus conditions in the soil after the harvest were studied. These results are reported in the present paper.

$$
\text { Field trials }
$$

Trial K 104 was on a fine sand soil, and trial $\mathrm{K} 105$ was on a humus soil. The experimental layout in both trials was the following:
1. No phosphate
2. Hyperphosphate $460 \mathrm{~kg} / \mathrm{ha}$
3. Superphosphate $800 \mathrm{~kg} / \mathrm{ha}$

The phosphate fertilizers were worked in with the basal dressing of $200 \mathrm{~kg} / \mathrm{ha}$ of $50 \%$ potash fertilizer in the autumn 1959 . In the spring $1960,100 \mathrm{~kg} / \mathrm{ha}$ of nitrochalk was applied as a surface dressing. 
According to the manufacturer's analysis, the hyperphosphate used contained $14.4 \%$ of $\mathrm{P}$, and the $\mathrm{P}$ content of the superphosphate was $8.3 \%$. Thus the amount of $\mathrm{P}$ applied in the two fertilizers was $66 \mathrm{~kg} / \mathrm{ha}$. During the previous experimental period of five years the total amount of $\mathrm{P}$ added in these two fertilizers was about $100 \mathrm{~kg} / \mathrm{ha}$.

The total area of the experimental plots was $50 \mathrm{~m}^{2}$. The harvested areas were $17.5 \mathrm{~m}^{2}$ in trial $\mathrm{K} 104$, and $25.2 \mathrm{~m}^{2}$ in trial $\mathrm{K} 105$. The treatments were in randomized blocks replicated four times.

The rye variety used in trial $\mathrm{K} 104$ was soivon-rye, which is known to be fairly susceptible to Fusarium nivale. In trial K 105 a native variety, "Vatian-rye, was grown. This variety may be considered very resistant to low-temperature parasitic fungi.

Plant samples were collected every tenth day from the 11th of May to the 10th of July. Each time 20 rye plants were cut from every plot. The samples were air-dried, and the straws and the ears were weighed and analyzed separately from each plot.

The soil samples were taken from the ploughing layer after the harvest in August 1960. Ten subsamples from every plot were collected and bulked. The samples were air-dried and ground before analyses.

\section{Analytical methods}

The plant samples were analyzed for total P using the ammoniumvanadate-molybdate method by GeRICKE and KURmies (3). An approximate fractionation method (4) was used for the estimation of the phosphorus composition of the plant material.

The pH-values of the soil samples refer to 1:2.5 water suspensions or to suspensions in $0.02 \mathrm{~N}$ $\mathrm{CaCl}_{2}$-solution in the same ratio.

The acetic acid soluble $\mathrm{P}$ was determined by shaking the soil sample for half an hour in $0.5 \mathrm{~N}$ acid in the ratio of 1:10. P soluble in $0.03 \mathrm{~N} \mathrm{NH}_{4} \mathrm{~F}-0.025 \mathrm{~N} \mathrm{HCl}$ was extracted in the ratio of $1: 10$ by shaking for one minute. The sexchangeable $\mathrm{P}$ and the $\mathrm{P}$ in equilibrium with the exchangeable $\mathrm{P}$ were determined by a modified method of TERÄSvUORI (9). The fractionation of inorganic P was performed by the method introduced by CHANG and JACKson (1).

\section{Results}

The density of stand in the field trials was visually estimated in the beginning of the growing period in the spring 1960. When the scale from 0 to 10 is used in which 10 means full density, the following numbers represent the conditions after overwintering (each mean represents 4 primary values with the same trend):

$\begin{array}{lcc} & \text { Trial K 104 } & \text { Trial K 105 } \\ \text { No phosphate } & 1.5 & 5.5 \\ \text { Hyperphosphate } & 3.5 & 6.5 \\ \text { Superphosphate } & 5.3 & \mathbf{8 . 0}\end{array}$

The thinning of the stand has been quite marked in trial $\mathrm{K} \mathrm{104}$, particularly in the plots without phosphate fertilizers. In both trials superphosphate appeared to be able to prevent the thinning to some degree, while hyperphosphate does not seem to be so effective.

One important cause for the differences in the density of stand may be found in the occurence of Fusarium in the various plots. The visual observations in Spring 1960 showed that the contamination had been very intensive in trial K 104 . 
in which the susceptible variety "Toivon was grown. In trial K 105 the native variety was more resistant. If 0 is taken to mean no Fusarium and 10 complete devastation of the stand, the following numbers were found:

$\begin{array}{lcc} & \text { Trial K } 104 & \text { Trial K } 105 \\ \text { No phosphate } & 8.5 & 4.7 \\ \text { Hyperphosphate } & 7.5 & 3.6 \\ \text { Superphosphate } & 5.8 & 2.7\end{array}$

Even in this case each mean represents 4 primary values with the same trend. Without phosphate the sprouts were very liable to infection with the snow mould in both trials. The application of hyperphosphate has not greatly improved the resistance, but the effect of superphosphate has been fairly good.

Also examination of the phosphorus content of the young rye plants in the Spring (May 11th) indicates that phosphorus nutrition probably plays an important role in overwintering - either directly or indirectly. The results of the analysis for total $\mathrm{P}$ content in the sprouts were the following:

No phosphate
Hyperphosphate
Superphosphate
L.S.D. $5 \%$

Trial K 104
$2.07 \mathrm{mg} / \mathrm{g}$
3.06 ,
3.69,
0.83,

Trial K 105
$2.13 \mathrm{mg} / \mathrm{g}$
2.79
4.45
0.69

These data show that the plants have been able to build material fairly rich in $\mathrm{P}$ when feeding on superphosphate, but that hyperphosphate has been a less available source of phosphorus for the rye seedlings. Without phosphate fertilizers the sprouts are poor in phosphorus.

The differences in the size of the variously treated sprouts were in trial $\mathrm{K} 105$ (humus soil) insignificant but in trial K 104 (fine sand soil) the superphosphate

Table 1. Dry weight of 20 rye plants, g

May 11 May 21 May 31 June 10 June 20 June 30 July 10

\begin{tabular}{lrrrrrrr}
\hline Trial K 104 & & & & & & & \\
No phosphate & 0.9 & 1.3 & 3.3 & 5.4 & 10.5 & 22.2 & 29.5 \\
Hyperphosphate & 1.2 & 1.9 & 6.0 & 13.2 & 25.6 & 33.7 & 48.6 \\
Superphosphate & 1.4 & 3.1 & 12.6 & 26.8 & 52.0 & 79.8 & 88.9 \\
L.S.D. 5\% & 0.2 & 0.5 & 2.0 & 6.1 & 10.3 & 14.0 & 23.7 \\
Trial K 105 & & & & & & & \\
No phosphate & 0.6 & 1.0 & 2.7 & 6.2 & 15.8 & 29.2 & 31.9 \\
Hyperphosphate & 0.7 & 1.3 & 3.9 & 10.0 & 21.5 & 44.6 & 48.0 \\
Superphosphate & 0.7 & 1.5 & 7.8 & 13.0 & 30.3 & 48.7 & 52.1 \\
L.S.D. 5\% & 0.3 & 0.1 & 0.8 & 1.7 & 5.6 & 6.9 & 11.4 \\
\hline
\end{tabular}


plants were bigger than the hyperphosphate plants and, particularly, the plants without phosphate fertilizers (Table 1). In trial K 104 the dry weight of the rye plants from the superphosphate plots remained distinctly higher than the weight of the plants from the hyperphosphate plots through the growing period, whereas from the end of June the difference between the weights of the latter and the weights of the plants from the untreated plots was no more statistically significant. In trial $\mathrm{K} 105$, on the other hand, the hyperphosphate plants were bigger than the plants without phosphate treatment and at the end of June they appeared to reach the level of the superphosphate plants.

The development of the ears seemed to be similar to the picture given by the data for the total plants. The dry weights of the ears of 20 rye plants are reported in Table 2.

Table 2. Dry weight of ears (g-per 20 plants).

\begin{tabular}{lcccc}
\hline & June 10 & June 20 & June 30 & July 10 \\
& & & & \\
\hline Trial K 104 & & & & \\
No phosphate & 0.3 & 1.7 & 3.1 & 5.4 \\
Hyperphosphate & 1.7 & 3.5 & 4.3 & 8.7 \\
Superphosphate & 4.0 & 6.4 & 9.1 & 16.6 \\
L.S.D 5\% & 0.1 & 1.4 & 1.6 & 4.6 \\
Trial K 105 & & & & \\
No phosphate & 0.3 & 1.6 & 3.3 & 4.2 \\
Hyperphosphate & 0.4 & 2.3 & 4.7 & 7.0 \\
Superphosphate & 0.8 & 3.6 & 5.0 & 7.6 \\
L.S.D. 5\% & 0.4 & 0.8 & 1.1 & 1.4 \\
\hline
\end{tabular}

Attention must be paid to the fact that the density of the stand exerts a marked effect on the tillering of the plants: the lower the density the more intensive the tillering. Thus the data for the weight of 20 plants give a too positive picture of the production of plant material in the plots with open stand. This also explains why the weights of 20 plants in trial $\mathrm{K} 104$ with a low density may be markedly higher than the corresponding weights in trial $\mathrm{K} 105$.

In Table 3 results are recorded of the uptake of $\mathrm{P}$ by 20 plants from the variously treated plots. The data reveal the superiority of superphosphate as a source of phosphorus to rye. Owing to the large variation the difference in the phosphorus uptake from untreated plots and from plots treated with hyperphosphate is not significant for all the sampling times.

The yield results, reported in Table 4, do not change the order of superiority of the treatments. The treatment with hyperphosphate has produced significant responses in the straw yields of both trials and also in the grain yield of trial K 104. Yet, the response to superphosphate was distinctly higher than that to hyperphos- 
Table 3. Uptake of phosphorus by rye ( $\mathrm{P} \mathrm{mg} / 20$ plants).

May 11 May 21 May 31 June 10 June 20 June 30 July 10

\begin{tabular}{lrrrrrrr}
\hline Trial K 104 & & & & & & & \\
No phosphate & 2 & 3 & 7 & 11 & 19 & 42 & 54 \\
Hyperphosphate & 4 & 5 & 13 & 20 & 42 & 59 & 87 \\
Superphosphate & 5 & 14 & 39 & 48 & 86 & 114 & 156 \\
\cline { 2 - 7 } L.S.D. 5\% & 1 & 2 & 6 & 10 & 18 & 29 & 41 \\
Trial K 105 & & & & & & & \\
No phosphate & 1 & 3 & 8 & 16 & 40 & 61 & 65 \\
Hyperphosphate & 2 & 4 & 15 & 28 & 55 & 95 & 99 \\
Superphosphate & 3 & 8 & 37 & 4 & 86 & 121 & 127 \\
L.S.D. 5\% & 1 & 1 & 3 & 5 & 18 & 20 & 23 \\
\hline
\end{tabular}

phate, the straw yield in trial K 105 being the only exception. Owing to the intensive decination of the stand in overwintering the level of the yields was very low in trial K 104.

Table 4. Yield results

\begin{tabular}{|c|c|c|c|c|c|}
\hline & $\begin{array}{l}\text { Grain } \\
\text { kg/ha }\end{array}$ & $\begin{array}{l}\text { Straw } \\
\mathrm{kg} / \mathrm{ha}\end{array}$ & $\begin{array}{c}\mathrm{P} \text { in grain } \\
\mathrm{g} / \mathrm{kg}\end{array}$ & $\begin{array}{c}\mathrm{P} \text { in straw } \\
\mathrm{g} / \mathrm{kg}\end{array}$ & $\begin{array}{c}\mathrm{P} \text { in yield } \\
\mathrm{kg} / \mathrm{ha}\end{array}$ \\
\hline \multicolumn{6}{|l|}{ Trial K 104} \\
\hline No phosphate & 210 & 1450 & 3.83 & 0.94 & 2.2 \\
\hline Hyperphosphate & 640 & 2280 & 4.30 & 0.91 & 4.8 \\
\hline Superphosphate & 880 & 2610 & 4.44 & 0.71 & 5.8 \\
\hline L.S.D. $5 \%$ & 90 & 310 & 0.15 & 0.17 & 0.3 \\
\hline \multicolumn{6}{|l|}{ Trial K 105} \\
\hline No phosphate & 1050 & 3860 & 3.98 & 0.84 & 7.4 \\
\hline Hyperphosphate & 1210 & 4550 & 4.07 & 0.76 & 8.4 \\
\hline Superphosphate & 1510 & 4590 & 4.48 & 0.97 & 11.2 \\
\hline L.S.D. $5 \%$ & 180 & 370 & 0.12 & 0.11 & 0.8 \\
\hline
\end{tabular}

Also in the phosphorus content of the grains the superiority of the superphosphate treatment is fairly marked. In the phosphorus content of straw the effect seems to be more complicated. In trial K 104 the low straw yield of untreated plots was able to produce material richer in phosphorus than the higher straw yield from the superphosphate plots. The latter appeared to be surprisingly poor in phosphorus. In trial K 105, on the other hand, the straw from the hyperphosphate plots tended to have the lowest phosphorus content.

It is interesting to note that the differences between the yields of phosphorus from the superphosphate plots and from the untreated ones were almost equal 
in both trials, or 3.6 and $3.8 \mathrm{~kg} / \mathrm{ha}$. The treatment with hyperphosphate, on the other hand has increased the yield of phosphorus by $2.6 \mathrm{~kg} / \mathrm{ha}$ in trial $\mathrm{K} 104$ and only by $1.0 \mathrm{~kg} / \mathrm{ha}$ in trial $\mathrm{K} 105$.

Table 5. Phosphorus fractions in grain and straw

(Expressed as $\mathrm{P} \mathrm{g} / \mathrm{kg}$ )

\begin{tabular}{|c|c|c|c|}
\hline & b & c & d \\
\hline $\begin{array}{l}\text { Inorg. } \mathrm{P} \\
\text { soluble in } \\
0,5 \mathrm{~N} \mathrm{HCl}\end{array}$ & $\begin{array}{l}\mathrm{P} \text { in } \\
\text { ethanol } \\
\text { extract }\end{array}$ & $\begin{array}{c}\text { Org. P } \\
\text { soluble in } \\
0.5 \times \mathrm{HCl}\end{array}$ & $\begin{array}{l}\mathrm{P} \text { in } \\
\text { residue }\end{array}$ \\
\hline
\end{tabular}

Trial K 104

\begin{tabular}{llllll} 
Grain & & & & \\
No phosphorus & 0.30 & 0.09 & 2.60 & 0.77 & 3.46 \\
Hyperphosphate & 0.35 & 0.08 & 3.15 & 0.75 & 3.98 \\
Superphosphate & 0.36 & 0.08 & 3.25 & 0.70 & 4.03 \\
\hline L.S.D. 5\% & 0.02 & 0.01 & 0.17 & 0.05 & 0.20 \\
Straw & & & & \\
No phosphate & 0.34 & 0.03 & 0.19 & 0.33 & 0.55 \\
Hyperphosphate & 0.47 & 0.02 & 0.13 & 0.24 & 0.39 \\
Superphosphate & 0.39 & 0.02 & 0.09 & 0.18 & 0.29 \\
L.S.D. 5\% & 0.08 & 0.005 & 0.04 & 0.05 & 0.09
\end{tabular}

Trial K 105

\begin{tabular}{|c|c|c|c|c|c|}
\hline Grain & & & & & \\
\hline No phosphate & 0.36 & 0.09 & 2.76 & 0.76 & 3.61 \\
\hline Hyperphosphate & 0.37 & 0.09 & 2.74 & 0.84 & 3.67 \\
\hline Superphosphate & 0.44 & 0.08 & 3.13 & 0.83 & 4.04 \\
\hline L.S.D. $5 \%$ & 0.03 & 0.01 & 0.12 & 0.05 & 0.12 \\
\hline Straw & & & & & \\
\hline No phosphate & 0.37 & 0.02 & 0.10 & 0.24 & 0.36 \\
\hline Hyperphosphate & 0.32 & 0.02 & 0.11 & 0.21 & 0.34 \\
\hline Superphosphate & 0.53 & 0.02 & 0.08 & 0.22 & 0.32 \\
\hline L.S.D. $5 \%$ & 0.08 & 0.01 & 0.05 & 0.03 & 0.06 \\
\hline
\end{tabular}

In Table 5 the results of the approximate fractionation of phosphorus in grain and straw are reported. Usually, above a certain minimum, a better supply of phosphorus is reflected in the higher content of inorganic phosphorus in vegetative material, or in the higher content of phytin phosphorus in seeds $(2,6,7$ etc.). In general, the present data corroborate these opinions, although some divergencies may be detected. In order to understand these, the fact must be taken into consideration that there were differences in the state of ripeness of the variously treated crops. In the plots where the devastation brought about by the low temperature parasitic fungi was marked, also the whole development of the plants and their 
maturing was retarded. The intensive tillering of the plants in plots with a low density of stand also exerted its effect on the irregular ripening. Thus, the yield harvested from the superphosphate plots represented a more mature and homogeneous material than that harvested from the hyperphosphate plots and, particularly, from the untreated plots.

The differences between state of ripening may be noted also from the following data which show the degree of moisture in the grains and 1000-grain weight of trial K 104 on August 4th, i.e. about 1 week before harvesting:

$\begin{array}{lcc} & \text { grain moisture } & \text { 1000-grain weight } \\ & \% & g \\ \text { No phosphate } & 50.4 & 13.7 \\ \text { Hyperphosphate } & 38.5 & 21.5 \\ \text { Superphosphate } & 35.5 & 22.2 \\ \text { L.S.D. 5\% } & 4.6 & 2.3\end{array}$

The soil analyses performed on samples collected in August 1960 may be expected to show the effect of the different treatments with phosphate during a period of six years. Thus, it may be supposed that the earlier applications of superphosphate and hyperphosphate phosphorus already have been retained by the soil components more intensively than the phosphate applied to the last rye crop.

Table 6. $\mathrm{pH}$-values and $\mathrm{P}$ condition in the soil in August 1960

\begin{tabular}{|c|c|c|c|c|c|c|}
\hline & \multicolumn{2}{|c|}{$\mathrm{pH}$} & \multirow{2}{*}{$\begin{array}{l}\text { Acetic acid } \\
\text { soluble P } \\
\text { ppm }\end{array}$} & \multirow{2}{*}{$\begin{array}{c}\mathrm{P} \text { soluble } \\
\text { in acid } \mathrm{NH}_{\mathbf{6}} \mathrm{F} \\
\text { ppm }\end{array}$} & \multirow{2}{*}{$\begin{array}{c}\text { Exchangeables } \\
\text { P } \\
\text { ppm }\end{array}$} & \multirow{2}{*}{$\begin{array}{l}\text { Cor- } \\
\text { responding } \\
\text { concentration } \\
\text { of } \mathrm{P} \mathrm{mg} / 1\end{array}$} \\
\hline & $\mathrm{H}_{2} \mathrm{O}$ & $\mathrm{CaCl}_{2}$ & & & & \\
\hline \multicolumn{7}{|l|}{ Trial K 104} \\
\hline No phosphate & 5.4 & 4.8 & 21 & 10 & 119 & 0.24 \\
\hline Hyperphosphate & 5.5 & 4.8 & 94 & 16 & 149 & 0.39 \\
\hline Superphosphate & 5.4 & 4.8 & 41 & 34 & 199 & 0.56 \\
\hline L.S.D. $5 \%$ & 0.1 & 0.05 & 34 & 8 & 28 & 0.14 \\
\hline \multicolumn{7}{|l|}{ Trial K 105} \\
\hline No phosphate & 5.6 & 5.2 & 104 & 6 & 74 & 0.07 \\
\hline Hyperphosphate & 5.7 & 5.2 & 213 & 7 & 75 & 0.10 \\
\hline Superphosphate & 5.7 & 5.2 & 142 & 18 & 138 & 0.25 \\
\hline L.S.D. $5 \%$ & 0.1 & 0.2 & 49 & 4 & 9 & 0.04 \\
\hline
\end{tabular}

The data in Table 6 indicate no noteworthy differences in the $\mathrm{pH}$-values of the variously treated soils. The fine sand soil of trial K 104 is more acid than the humus soil in trial $\mathrm{K} 105$, quite in accordance with the figures analyzed for these soils before the trials were started (cf. 5). The difference in the acidity and the calcium content of these soils also explains the differences in the various phosphorus 
test values. The acetic acid soluble $\mathrm{P}$ is higher in the less acid soil of trial $\mathrm{K} 105$, but the mainly aluminium and iron bound $\mathrm{P}$ soluble in the extraction solution of BRAY or occurring in the nexchangeablen form is higher in the more acid soil of trial K 104. The P concentration in the solution in equilibrium with the mexchangeable» $\mathrm{P}$ also tends to be higher in the fine sand soil of trial $\mathrm{K} 104$.

The application of hyperphosphate is reflected in the values for the acetic acid soluble $\mathrm{P}$ in both soils. There is also a tendency to higher figures in the superphosphate plots as compared to those of the untreated ones. Yet, owing to the large variation, the differences are not significant.

The superphosphate treatments have distinctly increased all the other test values, compared with the data for the untreated soils. Also the test values for the hyperphosphate plots are distinctly lower than those for the superphosphate ones. In the less acid soil of trial K 105 the treatment with hyperphosphate was not superior to no phosphaten. In trial $\mathrm{K} 104$, however, the hyperphosphate treatment may be noted in somewhat higher values for the nexchangeablen $\mathrm{P}$ and for the $\mathrm{P}$ concentration of the solution in equilibrium with this form of phosphorus.

Table 7. Inorganic $\mathrm{P}$ in the soil in August 1960

\begin{tabular}{|c|c|c|c|c|c|}
\hline & Al-Pr & ${ }_{n} \mathrm{Fe}-\mathrm{P}$ & ${ }_{9} \mathrm{Ca}-\mathrm{P}$ & $\begin{array}{c}\text { Reductant } \\
\text { soluble Fe-P }\end{array}$ & $\begin{array}{c}\text { Occluded } \\
\text { Al- and Fe-P }\end{array}$ \\
\hline & ppm & ppm & ppm & ppm & ppm \\
\hline \multicolumn{6}{|l|}{ Trial K 104} \\
\hline No phosphate & 18 & 117 & 270 & 70 & 7 \\
\hline Hyperphosphate & 27 & 127 & 319 & 69 & 7 \\
\hline Superphosphate & 50 & 148 & 276 & 63 & 9 \\
\hline L.S.D. $5 \%$ & 12 & 14 & 63 & 9 & 4 \\
\hline \multicolumn{6}{|l|}{ Trial K 105} \\
\hline No phosphate & 16 & 56 & 376 & 47 & 5 \\
\hline Hyperphosphate & 19 & 63 & 440 & 56 & 5 \\
\hline Superphosphate & 44 & 98 & 405 & 61 & 5 \\
\hline L.S.D. $5 \%$ & 5 & 11 & 50 & 20 & 1 \\
\hline
\end{tabular}

Owing to the large variation in the experimental fields, the results of the fractionation of the inorganic phosphorus in the soil also show less significant differences in the variously treated plots than could have been expected. The superphosphate phosphorus not taken up by the crops seems to have been accumulated particularly in the fractions of aluminum and iron bound phosphorus. In trial $\mathrm{K} 105$, there is some tendency also to an increase in the calcium-bound phosphorus of the superphosphate plots, but this cannot be considered significant. On the basis of the results of the fractionation, the hyperphosphate phosphorus has markedly increased only the calcium bound phosphorus values in trial K 105 . No differences exist in the fractions of the reductant soluble iron phosphorus or the occluded iron and aluminum phosphorus, as could be expected. 


\section{Discussion}

In Finland, usually about twice as much phosphorus as hyperphosphate than as superphosphate is needed for the production of equal increases in dry matter yields (8). Therefore, the previous results of the present trials appear to be somewhat exceptional (5). In trial K 105, the responses of oats, barley, oats and three harvests from red clover-timothy ley were equal to hyperphosphate and superphosphate. In trial $\mathrm{K} 104$ wheat and oats in the first two experimental years responded to superphosphate, but no increase in dry matter yields was produced by hyperphosphate. In the four subsequent years however, the treatments with superphosphate and hyperphosphate resulted in equally high increases in the dry matter yields of oats and three harvests from red clover-timothy leys. However, it was found that, at least in the hay yields harvested from the third year ley, fairly poor in red clover, the phosphorus content of the hay from hyperphosphate plots of both trials was markedly lower than that from the superphosphate plots.

The results reported in the present paper of the feeding of winter rye on hyperphosphate and superphosphate indisputably prove the superiority of superphosphate under the conditions of these trials. It seems probable that to a high degree this superiority of superphosphate may be considered to be caused by its better ability to supply the sprouts with enough phosphorus before the critical period of overwintering. The phosphorus content of the plants was not determined in the autumn, but early in the spring the plants treated with superphosphate were found to contain more phosphorus per dry matter than hyperphosphate plants or plants from the untreated plots. In accordance with this fact, the density of stand in the spring was highest in the superphosphate plots of both trials.

The winter $1959-60$ was a fairly bad snow mould season. The occurence of Fusarium nivale was abundant particularly in trial K 104 in which a susceptible variety, "Toivon-rye, was grown. Also in trial $\mathrm{K} 105$ with a more resistant native rye variety the devastation caused by Fusarium was marked. It may be mentioned that the microclimatic conditions of trial K 105 were more unfavourable than those of trial K 104. In both trials the occurence of Fusarium was lowest on the plots treated with superphosphate and highest on the untreated plots. Thus the application of superphosphate has been able to decrease the devastation brought about by the low-temperature parasitic fungi, but it has not been able to prevent it totally. The positive effect of hyperphosphate was distincty lower, yet observable. Although there are probably other factors too which exert their effect on the keeping of the stand over the winter and which are connected with the phosphorus nutrition of the plants, the influence of the phosphorus supply on the resistance towards the low temperature parasitic fungi seems to be one of the most important.

In addition to the thinning of the stand, another consequence of the infection by the snow mould seems to be a distinct retardation in the development of the plants. This retardation has also been detected in several fungicide trials with winter wheat carried out in Central Finland by one of the authors.

In the present trials the plants in the superphosphate plots were more vigorous than those in the hyperphosphate plots in the beginning of the growing period, 
and they also retained their superiority until the harvest. According to TENnBERG (8), the response of winter rye to hyperphosphate has been, on the average, 58 per cent on mineral soils and 68 per cent on organic soils of the response of winter rye to superphosphate. In trial K 104 the increase in the grain yield produced by hyperphosphate was 64 per cent of that produced by superphosphate. The corresponding value for the straw yields was 71 per cent. In trial K 105 the increase in grain yield brought about by the treatment with hyperphosphate was only 35 per cent of that obtained by the treatment with superphosphate. In the increases in the straw yields the difference was insignificant.

The amount of phosphorus in the yield of the hyperphosphate plots was in trial $\mathrm{K} 1042.6 \mathrm{~kg} /$ ha higher than that of the untreated plots, but in trial $\mathrm{K} 105$ the difference was only $1 \mathrm{~kg} / \mathrm{ha}$. Yet, too many factors are involved to justify the alluring conclusion that hyperphosphate had been more effective on the more acid soil of trial K 104. There are e.g. the exceptionally low level of the yield and uptake of phosphorus in trial $\mathrm{K} \mathrm{104}$, and the differences in the maturing of the crop in these trials. However, the differences in the amounts of phosphorus in the yields of the superphosphate plots and the untreated plots are almost equal in both trials, or 3.6 and $3.8 \mathrm{~kg} / \mathrm{ha}$.

It may be emphasized that in these trials not only the effect of the treatments of the rye crop but also the residual effect of the treatments during six years must be taken into consideration. Since the residual effect of hyperphosphate usually seems to be somewhat higher than the residual effect of superphosphate, it could be supposed that the difference between the response of rye to these fertilizers would be somewhat lower than if only an instant effect were in question. On the other hand, the application of phosphorus to the rye crops was so high that it decreases the importance of the residual effect.

The soil analyses did not present anything new about the effect of these two fertilizers on the phosphorus fractions and phosphorus test values of the soil. In the less acid soil of trial K 105 hyperphosphate phosphorus seems to be found almost completely as calcium bound phosphorus whereas it has also increased in the more acid fine sand soil of trial K 104 some of the test values representing aluminium and iron bound phosphorus.

\section{$S u m m$ ar $y$}

The response of winter rye to hyperphosphate and superphosphate was studied in two field trials, previously carried out for 6 years with other crops. The amount of phosphorus applied to the rye crop in these two fertilizers was $66 \mathrm{~kg} / \mathrm{ha}$, the earlier applications amounted to $100 \mathrm{~kg} / \mathrm{ha}$.

The superiority of superphosphate as a source of phosphorus to winter rye was in the both trials more or less distinct throughout the growing period, as could be shown by the dry matter weight and phosphorus uptake of rye plants from May to the middle of July, and by the actual yield results. 
It is assumed that an important cause for the superiority of superphosphate may be found in the fact that plants feeding on it are able to grow sprouts vigorous enough to endure the hard conditions of overwintering in our country. Particularly, the devastation caused by the low temperature parasitic fungi was in these two trials distincly decreased by the treatment with superphosphate. The positive effect of hyperphosphate was markedly lower.

The soil analyses indicated that the hyperphosphate phosphorus occurred both in the more acid fine sand soil and, especially, in the less acid organic soil mostly in the calcium bound form, whereas the effect of superphosphate could be detected in the somewhat higher test values for aluminum and iron bound phosphorus.

\section{REFERENCES}

(1) Chang, S. C. \& JAckson, M. L. 1957. Fractionation of soil phosphorus. Soil Sci. 84: 133-144.

(2) Garz, J. 1957. Zur Kenntnis der Phosphaternährung der Luzerne. Zeitschr. f. Pflanzenern., Düng., Bodenk. 79: 213-232.

(3) Gericke, S. \& Kurmies, B. 1952. Die kolorimetrische Phosphorsäurebestimmung mit AmmoniumVanadat-Molybdat und ihre Anwendung in der Pflanzenanalyse. Ibid. 59: 235-247.

(4) KaILA, A. 1952: Observations on the effect of nitrogen and phosphorus upon the humification of straw. Acta Agr. Fennica 78, 2.

(5) - - \& Hänninen, P. 1960. Response of ley plants to rock phosphate and superphosphate. J. Sci. Agric. Soc. Finland 32: 52-61.

(6) Michael, G. 1939. Phosphorsäurefraktionen in Haferkorn und Spinatblättern in Abhängigkeit von verschiedener Phosphorsäuredüngung. Bodenk. u. Pflanzenern. 14: 148-171.

(7) Schmalfuss, K. 1941. Uber die Wandlungen der Phosphorverbindungen in der reifenden Maisfrucht, in Sonderheit bei verschiedener Ernährung der Pflanze. Ibid. 20: 151-177.

(8) Tennberg, F. 1960. Fosforilannoituksen vaikutuksesta satomääriin Suomessa. Reprint from Rikkihappo- ja superfosfaattitehtaat oy 40 vuotta, 34 p., Helsinki.

(9) TERĀSvUORI, A. 1954. Über die Anwendung saurer Extraktionslösungen zur Bestimmung des Phosphordüngerbedarfs des Bodens, nebst theoretischen Erörterungen über den Phosphorzustand des Bodens. Staatl. Landw. Versuchstätigkeit, Veröff. Nr. 141, Helsinki.

S E L O T U S :

HIENOFOSFAATTI JA SUPERFOSFAATTI RUKIIN FOSFORIN LÄHTEENÄ

Armi KaILA

Yliopiston maanviljelyskemian laitos, Helsinki

ja

Pentti Hänninen

Maatalouden tutkimuskeskus, Keski-Suomen liikkuva koetoiminta, Kuusa

Kahta aikaisemmin (5) selostettua kenttäkoetta jatkettiin vv. 1959-60 Keski-Suomessa ruis koekasvina. Rukiille annettiin hienofosfaattina tai superfosfaattina fosforia $66 \mathrm{~kg} / \mathrm{ha}$, edellisinä vuosina lannoituksena annetun fosforin määrä oli yhteensä $100 \mathrm{~kg} / \mathrm{ha}$.

Molemmissa kokeissa superfosfaatti osoittautui selvästi hienofosfaattia paremmaksi fosfori- 
lannoitteeksi rukiille. Tämä oli todettavissa sekä kasvukauden aikana kerättyjen kasvinäytteiden kuivaaineen määrän ja fosforin oton sekä etenkin varsinaisten satotulosten perusteella.

Eräänä tärkeänä syynä superfosfaatin paremmuuteen rukiin fosforin lähteenä on ilmeisesti sen kyky tarjota kasville mahdollisuus kehittää ennen talvehtimista voimakas ja riittävästi fosforia sisältävä oras. Molemmissa kokeissa havaittiin superfosfaatin vähentäneen selvästi lumihomeen saastutusta ja siten estäneen kasvuston harvenemista suhteellisesti paremmin kuin hienofosfaattilannoituksen.

Maa-analyysien perusteella näytti hienofosfaatin fosfori kertyneen lähinnä kalsiumin sitomana muotona, kun taas superfosfaatti oli lisännyt etupäässä raudan ja aluminiumin sitomaa fosforia. 